\title{
STRUCTURE INVESTIGATIONS OF BINARY PHOSPHATE GLASSES
}

\author{
ANDREA BARZ and DÖRTE STACHEL \\ Otto Schott Institute, Faculty of Chemistry and Earth Sciences, University Jena, \\ Fraunhoferstr. 6, D- 07743 Jena, Germany
}

\begin{abstract}
Structure investigations were performed on several glass series of $\mathrm{xMeO} \cdot(1-\mathrm{x}) \mathrm{P}_{2} \mathrm{O}_{5}$ with $\mathrm{Me}=\mathrm{Mg}, \mathrm{Ca}, \mathrm{Zn}$ and $\mathrm{x}$ ranging from 0 to 0,5 using modern structure sensitive methods, like ${ }^{31} \mathrm{P}$ MAS NMR, IR spectroscopy, x-ray scattering. As reference sample new well definded polymer crystalline ultrphosphates were used. The results are presented on example of the glass system $\mathrm{ZnO}-\mathrm{P}_{2} \mathrm{O}_{5}$.
\end{abstract}

\section{INTRODUCTION}

While the structure of silica glasses is well known for phosphate glasses doesn't exist a sufficient structural model. The structure concepts of these glasses predominantly base on the theory of van Wazer. ${ }^{1}$ It describes a monotonous change of glass structure and properties in dependence on composition as a result of a continuous distribution of structure units in glass. However, discontinuous changes of composition-propertyrelations which were found in phosphate glasses can't be explained by this model.

The main part of investigations confines to glasses containing higher amounts of network modifier than phosphorus pentoxid. About the concentration range between 0 and $50 \mathrm{~mol} \%$ network modifier oxide, the so called ultraphosphate range, there are only few publications. The reasons are probably the evaporation of phosphorus pentoxide during melting and difficult handling because of the hygroscopic behaviour of this and the glasses.

The aim of our investigations was to study the structure of ultraphosphate glasses by combination of independent, structure-sensitive methods, like ${ }^{31} \mathrm{P}$ - NMR, IRspectroscopy and X-ray diffraction. A comparison of new well defined crystalline ultraphosphates with their corresponding glasses should give information about 
structural similarities and differences.

The investigations were performed on several glass series of $\mathrm{x} \mathrm{MeO} \cdot(1-\mathrm{x}) \mathrm{P}_{2} \mathrm{O}_{5}$ with $\mathrm{Me}$ $=\mathrm{Mg}, \mathrm{Ca}$ and $\mathrm{Zn}$ and $\mathrm{x}$ ranging from 0 to 0,5. All glasses were prepared using "waterpoor" technique of sealed, evacuated $\mathrm{SiO}_{2}$ glass tubes. ${ }^{2}$

\section{RESULTS AND DISCUSSION}

The structure units of phosphate network can be classified by the $Q^{n}$ terminology, where $\mathrm{n}$ is the number of bridging oxygens in a $\mathrm{PO}_{4}$ group. As metal oxide $(\mathrm{MeO})$ is added to phosphorus pentoxide $\left(\mathrm{P}_{2} \mathrm{O}_{5}\right)$, the phosphate structural groups convert from $\mathrm{Q}^{3}$ to $\mathrm{Q}^{2}$ then to $\mathrm{Q}^{1}$ and finally to $\mathrm{Q}^{0}$. According to van Wazer, the structure of $\mathrm{P}_{2} \mathrm{O}_{5}$ glass is solely formed by $\mathrm{Q}^{3}$ groups. Ultraphosphates consist of statistically distributed $\mathrm{Q}^{3}$ and $\mathrm{Q}^{2}$ groups. Metaphosphate is formed by $\mathrm{Q}^{2}{ }^{1}$

${ }^{31} \mathrm{P}-\mathrm{NMR}$ spectroscopy gives information about the kinds of the $\mathrm{PO}_{4}$ tetrahedra in crystalline materials and glasses. In the $\mathrm{ZnO}-\mathrm{P}_{2} \mathrm{O}_{5}$ system, the number of $\mathrm{Q}^{3}$ groups

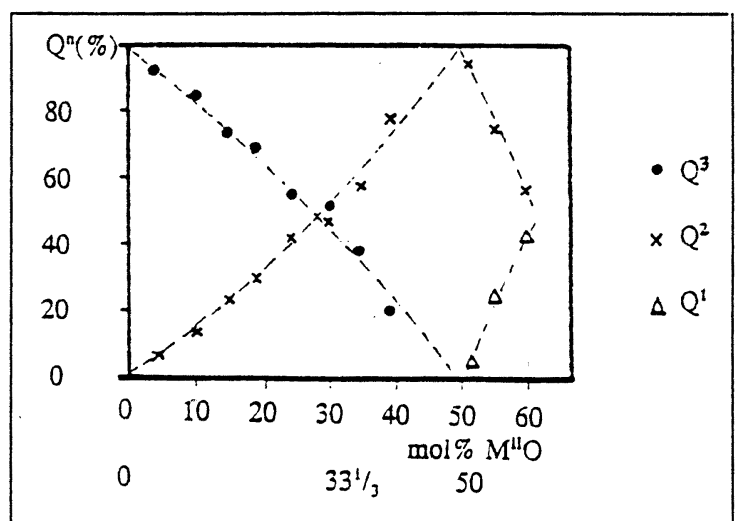

FIGURE 1. Change of the amount of $\mathrm{Q}^{3}$ and $\mathrm{Q}^{2}$ groups with increasing $\mathrm{ZnO}$ content continuously decreases with increasing $\mathrm{ZnO}$ content, whereas the number of $Q^{2}$ groups increases (fig.1). Other $\mathrm{Q}^{\mathrm{n}}$ groups don't occur in the region between $\mathrm{P}_{2} \mathrm{O}_{5}$ and $\mathrm{Zn}\left(\mathrm{PO}_{3}\right)_{2}$ composition. These results confirm the theory of van Wazer.

For glass structure, not only the knowledge of kind and number of characteristic polyhedra are important but also its interconnection. By help of X-ray scattering, it was possible to determine atom distances and coordination numbers of the atoms. Furthermore, this method gives information about the intermediate range order of glass by evaluation of the main diffraction peak. The position of maximum and full widths half maximum of this peak reflect the distance between characteristic repetitive arrangements of atoms and their range of periodicity. ${ }^{3}$

In the $\mathrm{ZnO}-\mathrm{P}_{2} \mathrm{O}_{5}$ system, the average range of periodicity of these characteristic units is 
$0,9 \mathrm{~nm}$. The good agreement of the scattering curves of the crystalline compounds of this system with the corresponding glass indicates a similar structure of crystal and glass. $^{4}$

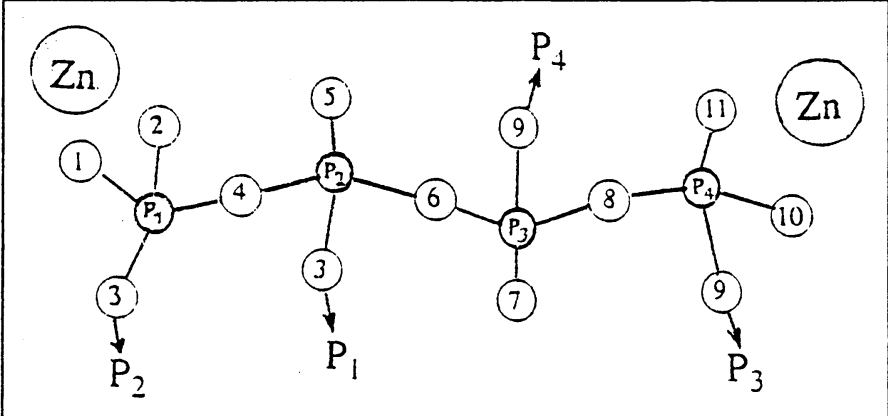

FIGURE 2. The smallest structure unit of $\mathrm{ZnP}_{4} \mathrm{O}_{11}$
Information about the short and intermediate range order of crystal and glass are also obtained by IR spectroscopy. It was found that the IR s pectrum of a crystalline compound in

the range of valence vibrations can be described by a minimal number of stretching vibrations calculated from the crystallographically non-equivalent $\mathrm{PO}_{4}$ tetrahedra of the crystal structure. These tetrahedra are connected to form the smallest structure unit. The interconnection of these units forms the crystal structure. The smallest structure unit of zinc ultraphosphate $\mathrm{ZnP}_{4} \mathrm{O}_{11}$ is shown in figure 2.5

In the $\mathrm{ZnO}-\mathrm{P}_{2} \mathrm{O}_{5}$ system, the IR spectra of the investigated glasses correspond with the related crystals. This suggests that the kinds of structure units and their interconnection within a characteristic range is nearly the same. ${ }^{6}$ An example is given in figure 3 for crystalline $\mathrm{ZnP}_{4} \mathrm{O}_{11}$ and the corresponding glass.

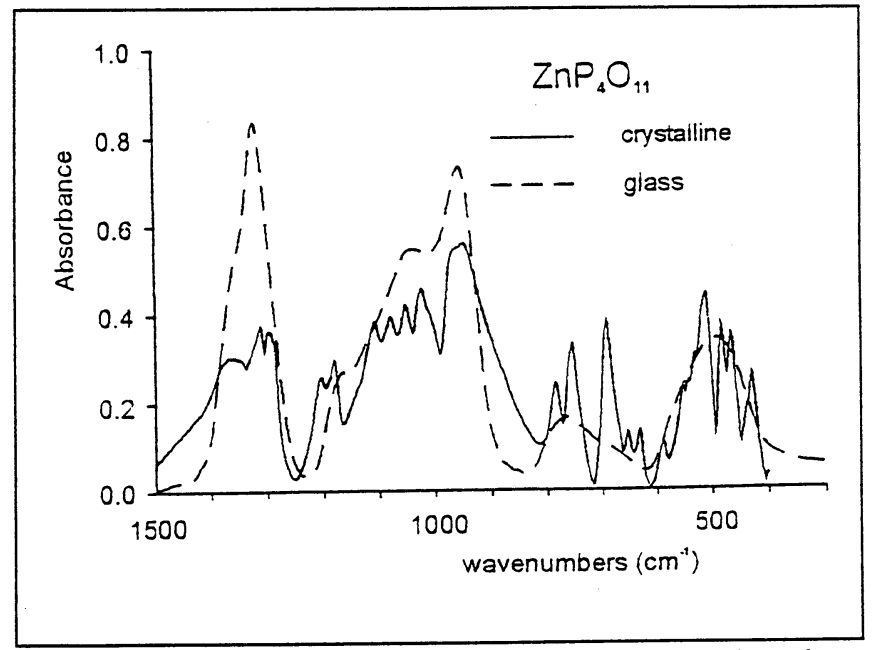

FIGURE 3. IR specta of crystalline zinc ultraphosphate $\mathrm{ZnP}_{4} \mathrm{O}_{11}$ and the related glass

The IR spectra of zinc phosphate glasses show typical changes in the region from 0 to $50 \mathrm{~mol} \% \mathrm{ZnO}$. With the help of factor analysis, 3 spectroscopic components were 
found. They are identical with the spectra of $\mathrm{P}_{2} \mathrm{O}_{5}$ glass $(0 \mathrm{~mol} \% \mathrm{ZnO}), \mathrm{ZnP}_{4} \mathrm{O}_{11}$ glass (33 $\mathrm{mol} \% \mathrm{ZnO}$ ) and metaphosphate glass $(50 \mathrm{~mol} \% \mathrm{ZnO}$ ). The proportions of the components in the spectra of the glasses were calculated and are given in table 1 together with the theoretical portion calculated from the analyzed $\mathrm{ZnO}$ content. ${ }^{7}$ In the range from 0 to $33 \mathrm{~mol} \%$ the glass structure is formed by the structure elements of $\mathrm{P}_{2} \mathrm{O}_{5}$ glass and $\mathrm{ZnP}_{4} \mathrm{O}_{11}$ glass. Whereas, in the region from 33 to $50 \mathrm{~mol} \%$ it conists of structure units of $\mathrm{ZnP}_{4} \mathrm{O}_{11}$ glass and metaphosphate glass.

TABLE 1 Composition of the glasses investigated $\left(\mathrm{ZnUP}=\mathrm{ZnP}_{4} \mathrm{O}_{11}, \mathrm{ZnMP}=\mathrm{Zn}\left(\mathrm{PO}_{3}\right)_{2}\right)$

\begin{tabular}{||l|l|l|l|l|l|l||}
\hline \hline \multirow{2}{*}{$\begin{array}{l}\mathrm{ZnO}- \\
\text { content } \\
{[\mathrm{mol} \%]}\end{array}$} & \multicolumn{3}{|l|}{ theoretical content [mol\%] } & \multicolumn{4}{l|}{ calculated content [mol\%] } \\
\cline { 2 - 8 } & $\mathrm{P}_{2} \mathrm{O}_{5}$ & $\mathrm{ZnUP}$ & $\mathrm{ZnMP}$ & $\mathrm{P}_{2} \mathrm{O}_{5}$ & ZnUP & ZnMP \\
\hline 0 & 100 & 0 & 0 & 100 & 0 & 0 \\
\hline 4,7 & 86 & 14 & 0 & 91 & 9 & 0 \\
\hline 10,4 & 69 & 31 & 0 & 84 & 16 & 0 \\
\hline 5,0 & 55 & 45 & 0 & 69 & 31 & 0 \\
\hline 19,1 & 42 & 57 & 0 & 53 & 47 & 0 \\
\hline 24,6 & 26 & 74 & 0 & 16 & 84 & 0 \\
\hline 30,3 & 9 & 91 & 0 & 10 & 90 & 0 \\
\hline 32,0 & 4 & 96 & 0 & 11 & 89 & 0 \\
\hline $32,4 \mathrm{c}$ & 3 & 97 & 0 & 3 & 97 & 0 \\
\hline 39,4 & 0 & 63 & 37 & 0 & 69 & 31 \\
\hline 43,4 & 0 & 40 & 60 & 0 & 14 & 86 \\
\hline 50,0 & 0 & 0 & 100 & 0 & 0 & 100 \\
\hline
\end{tabular}

A binary distribution model for the $\mathrm{ZnO}-\mathrm{P}_{2} \mathrm{O}_{5}$ system was developed from these results (figure 4). It can also be applied for the other investigated systems $\mathrm{MgO}-\mathrm{P}_{2} \mathrm{O}_{5}$ and $\mathrm{CaO}-\mathrm{P}_{2} \mathrm{O}_{5}$.

\section{$\underline{\text { SUMMARY }}$}

In summary, the structure of a glass with stochiometric composition solely contains the structure elements of the related crystalline compound. By contrast, in the 
concentration range between two compounds, the glass structure consists of two structure units given by the two limiting compounds. The structural difference between glass and crystal is determined by its order, not by its structure elements.

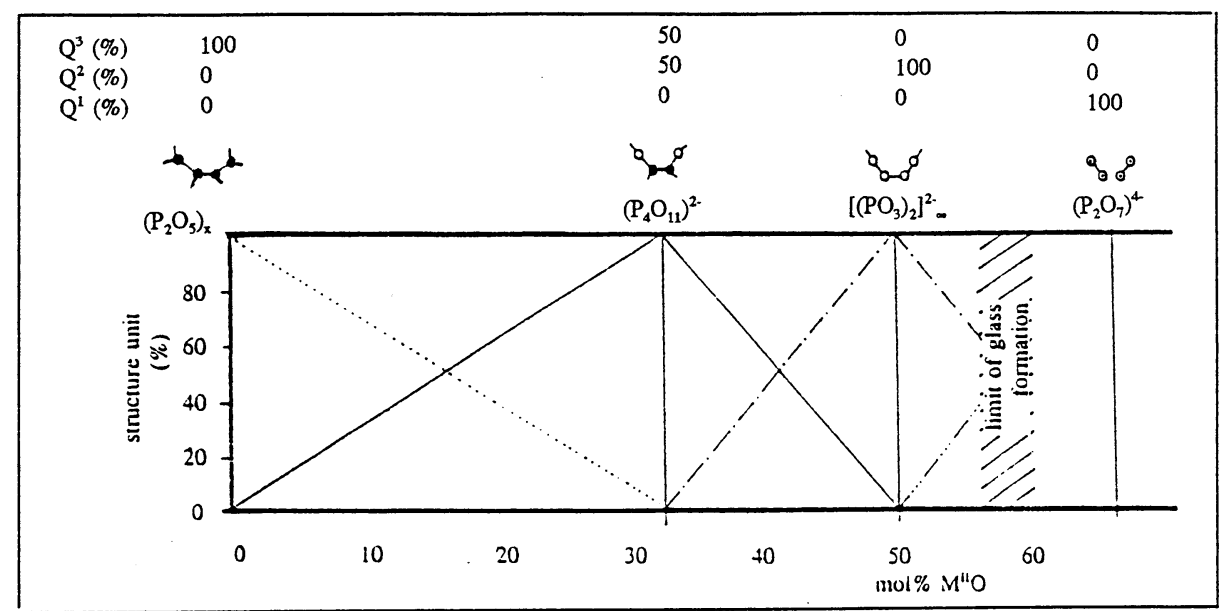

FIGURE 4. Binary distribution model for the $\mathrm{ZnO}-\mathrm{P}_{2} \mathrm{O}_{5}$ system

\section{ACKNOWLEDGMENT}

We thank Dr. P. Losso for ${ }^{31}$ P-NMR-, Dr. K. Meyer for IR- and Dr. G.Walter for the X-ray scattering measurements. For finacial support, we kindly thank the Deutsche Forschungsgemeinschaft.

\section{REFERENCES}

1 J. R. Van Wazer, Phosphorus and Its Compounds, Vol. I; Interscience Publishers, 1958

2 D. Stachel, C. Bäz-Dölle, H. Reiß, XVI. Int.Congr. on Glass,Madrid 1992, Vol.3, 1858

3 G. Walter, U. Hoppe, R. Kranold, D. Stachel, Phys. Chem. Glasses, 35 (1994) 245

4 G. Walter, U. Hoppe, T. Baade, R. Kranold, D. Stachel, Glastechn. Ber. Glass Sci. Technol. $\underline{67 \mathrm{C}}$ (1994) 185

5 C. Bäz-Dölle, D. Stachel, I. Svoboda, H. Fuess, Z. Kristallogr. 203 (1993) 282

6 K. Meyer, A. Barz, H. Hobert, D. Stachel, Vib. Spectrosc., $\underline{6}$ (1994) 323

7 A. Barz, K. Meyer, D. Stachel, Glastechn. Ber. Glass Sci. Technol., 68 C1 (1995) 79 